SHORT COMMUNICATION

\title{
New record of Blepharicnema splendens (Diptera, Calliphoridae, Luciliini) and range expansion in Caquetá, Colombia
}

\author{
Yardany RAMOS-PASTRANA ${ }^{1,2 *}$ ๑), Eric CÓRDOBA-SUAREZ ${ }^{1}$, Marta WOLFF² \\ Universidad de la Amazonia, Grupo de Investigación en Entomología -GIEUA-, Laboratorio de Entomología, Florencia, Caquetá, Colombia \\ 2 Universidad de Antioquia, Instituto de Biología, Grupo de Entomología -GEAU-, Medellín, Colombia \\ * Corresponding author: ya.ramos@udla.edu.co; (D) https://orcid.org/0000-0002-3193-6659
}

\begin{abstract}
Blepharicnema splendens is a dipteran with occurrence restricted to the Neotropical Andean mountain forests from 1,400 to 2,500 masl. We surveyed the species using Van Someren-Rydon traps with decaying fish as bait in four sites (veredas) in the Eastern Cordillera, in the Municipality of Florencia, Caquetá, Colombia. A total of 221 individuals were collected in the four localities. The Vereda Las Brisas had the highest abundance, with 104 specimens (45.4\%), followed by El Vergel, 76 (33.2\%), Tarqui, $46(20.1 \%)$ and Los Lirios, 2 (0.9\%). The record of this species in the mountainous ecosystems of the Department of Caquetá expands the known distribution of $B$. splendens and adds to the incipient knowledge on the diversity of Diptera in this region.
\end{abstract}

KEYWORDS: biodiversity, Andean-Amazon region, distribution, Van Someren-Rydon

\section{Novo registro de Blepharicnema splendens (Diptera, Calliphoridae, Luciliini) e expansão de sua área de distribuição em Caquetá, Colômbia}

\section{RESUMO}

Blepharicnema splendens é um dipetero de ocorrência restrita às florestas montanhosas dos Andes neotropicais de 1400 até 2500 $\mathrm{m}$ acima do nível do mar. Amostramos a espécie utilizando armadilhas Van Someren-Rydon, com peixe em decomposição como isca, em quatro localidades (veredas) na Cordilheira Oriental, no município de Florencia, Caquetá, Côlombia. Foram coletados 221 indivíduos nas quatro localidades. A maior abundância foi registrada na Vereda Las Brisas, com 104 espécimes (45,4\%), seguido de El Vergel, 76 (33,2\%), Tarqui, 46 (20,1\%) e Los Lirios, 2 (0,9\%). O registro dessa espécie nos ecossistemas montanhosos do Departamento de Caquetá é uma expansão da distribuição atualmente conhecida de $B$. splendens, e contribui ao conhecimento incipiente sobre a diversidade de dípteros nessa região.

PALAVRAS-CHAVE: biodiversidade, Região Andino-Amazônica, distribuição, Van Someren-Rydon

Calliphoridae is commonly known as a cosmopolitan and heterogeneous family, composed of about 1,000 species distributed in approximately 150 genera (Thompson 2008). In the Neotropical region, more than 120 species are known (Kosmann et al. 2013) and for Colombia there are 31 recorded species, distributed in four subfamilies and 12 genera (Wolff and Kossmann 2016).

Blepharicnema Macquart, 1843 is a monotypic genus, represented by Blepharicnema splendens (Macquart, 1843). The species was subsequently redescribed by Mariluis (1979), however its type locality is still unknown. The genus is characterized by its large size, from 12 to $14 \mathrm{~mm}$, metallic green coloration, and abundant hairs on the legs. They are frequently collected using decaying fish as bait (Amat and Wolff 2007). It is distributed in the Andean zone from Bolivia to Venezuela, in high areas of well preserved Andean forest (Amat and Wolff 2007).

In Colombia, B. splendens has been reported in the departments of Antioquia, Caldas, Cundinamarca, Magdalena, Risaralda, Santander, and Valle del Cauca, based on 49 specimens (Amat and Wolff 2007). There is only one record in the Colombian Amazonian region, in the Department of Putumayo (Pape et al. 2004). This study reports B. splendens for the Department of Caquetá, Colombia, and updates its geographical distribution.

The study was developed in the Municipality of Florencia, Caquetá, located in the Colombian Andean Amazon 
$\left(1^{\circ} 37^{\prime} 03^{\prime \prime} \mathrm{N}, 75^{\circ} 37^{\prime} 03^{\prime \prime} \mathrm{W}\right)$. The average annual rainfall is $3,840 \mathrm{~mm}$, decreasing between September and February, the less rainy season in the region, while it increases between March and August, the rainy season, when the temperature tends to decrease (IGAC 2010). Four sampling areas were selected, corresponding to the city zones (veredas) El Vergel, Las Brisas, Tarqui and Los Lirios, all located between 1,400 and 2,400 masl.

Vereda El Vergel: the collection site was at El Pórtico, located at $\mathrm{km} 49$ of the road between the municipalities of Florencia,

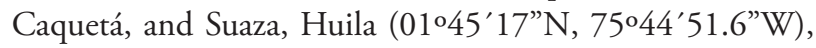
at an altitude of 2,400 masl. It is characterized by a cold climate and cloud forest (IGAC 2010), with a yearly average temperature of $15^{\circ} \mathrm{C}$. The site corresponds to an area of montane forest (Holdridge 1996).

Vereda Las Brisas: the collection site was at Túnel III, located at $\mathrm{km} 46$ of the same road from Florencia to Suaza $\left(01^{\circ} 45^{\prime} 14^{\prime \prime} \mathrm{N}, 75^{\circ} 44^{\prime} 51.5^{\prime \prime} \mathrm{W}\right)$, at an altitude of 2,040 masl, with vegetation and temperature similar to El Pórtico.

Vereda Tarqui: collection site located at $\mathrm{km} 44$ of the road to the municipality of Guadalupe, Huila $\left(01^{\circ} 51^{\prime} 02^{\prime \prime} \mathrm{N}\right.$, $\left.75^{\circ} 40^{\prime} 28.4^{\prime \prime} \mathrm{W}\right)$, at an altitude of 2,020 masl, with vegetation and temperature similar to El Pórtico.

Vereda Los Lirios: collection site located at $\mathrm{km} 28$ of the road from Florencia to Suaza $\left(01^{\circ} 45^{\prime} 14{ }^{\prime \prime} \mathrm{N}, 75^{\circ} 43^{\prime} 13.6^{\prime \prime W}\right)$, at an altitude of 1,400 masl, and characterized by a medium or temperate climate and premontane pluvial forest (IGAC 2010), dominated by plants belonging to the family Rubiaceae, with an average temperature of $18^{\circ} \mathrm{C}$. The site corresponds to an area of low montane forest (Holdridge 1996).

The collections were made randomly, between 2011 and 2018, using Van Someren-Rydon traps baited with approximately $150 \mathrm{~g}$ of decaying fish, set at approximately $130 \mathrm{~cm}$ from the ground, and left for a period of 36 hours. Additional material was collected with entomological nets in the areas around the traps. All specimens were brought to the entomology laboratory of Universidad de la Amazonia, where the material was sorted, counted, sexed, and identified with the keys proposed by Amat et al. (2008) and Vargas and Wood (2010), using an Olympus SZ2-ILST stereomicroscope. All specimens were deposited in the entomological collection of Universidad de la Amazonia (LEUA; Registro Nacional de Colecciones (RNC) in process) in Florencia, Caquetá, Colombia.

The photograph of the specimen (Figure 1) was taken under a stereomicroscope Leica M205A, using a camera Leica DFC450. The distribution map (Figure 2) was composed in QGIS v.2.8.3 (QGIS Development Team, 2018) using World-Clim elevation data (Hijmans et al. 2005) and the field coordinates were taken in degree format.
A total of 221 specimens of B. splendens (Figure 1) were collected (104 in Las Brisas, 76 in El Vergel, 46 in Tarqui, and two in Los Lirios). The species was found mainly in cloud and tropical rainforest, between 1,400 and 2,400 masl.

Material examined. Colombia, Caquetá, Florencia, Vereda El Vergel, 2.400 m, 69, 25.xi.2011, Y. Ramos-Pastrana, Vsr. Trap baited with fish (LEUA-600 to 605). 24.xi.2011, 89, Y. Ramos-Pastrana, Vsr. Trap baited with fish (LEUA-606, LEUA-607 to 613). 24.xi.2011, 49, Y. Ramos-Pastrana, jama (LEUA-614 to 617). 10.vi.2011, 19, Y. Ramos-Pastrana, Vsr. Trap baited with fish (LEUA-618). 03.vi.2011, 49, Y. RamosPastrana, Vsr. Trap baited with fish (LEUA-619 to 622). 3.iii.2011, 39, Y. Ramos-Pastrana, Vsr. Trap baited with fish (LEUA-623 to 625). 16.v.2013, 29, Y. Ramos-Pastrana, Vsr. Trap baited with fish (LEUA-626, LEUA-627). 15.v.2014, $10^{7}, 479$, Y. Ramos-Pastrana, Vsr. Trap baited with fish (male: LEUA-628; females: LEUA-629 to 675). 13.v.2014, 10, Y. Ramos-Pastrana, Vsr. Trap baited with fish (LEUA-676). 11.v.2014, 19, Y. Ramos-Pastrana, Vsr. Trap baited with fish (LEUA-677). Vereda Las Brisas, 2.040 m, 23.xi.2011, 19, Y. Ramos-Pastrana, Vsr. Trap baited with fish (LEUA-678). 25.xi.2011, 19, Y. Ramos-Pastrana, Vsr. Trap baited with fish (LEUA-679). 25.v.2012, 30', 29, Y. Ramos-Pastrana, Vsr. Trap baited with fish (males: LEUA-680 to 682; females: LEUA683, LEUA-684). 17.v.2013, 229, Y. Ramos-Pastrana, Vsr. Trap baited with fish (LEUA-685 to 706). 16.v.2016, $90^{\pi}$, 20\%, Y. Ramos-Pastrana, Vsr. Trap baited with fish (males: LEUA707 to 715 ; females: LEUA-716 to 735). 17.v.2016, 20', 79, Y. Ramos-Pastrana, Vsr. Trap baited with fish (males: LEUA736, LEUA-737; females: LEUA-738 to 744). 19.v.2016, $10^{7}, 129$, Y. Ramos-Pastrana, Vsr. Trap baited with fish

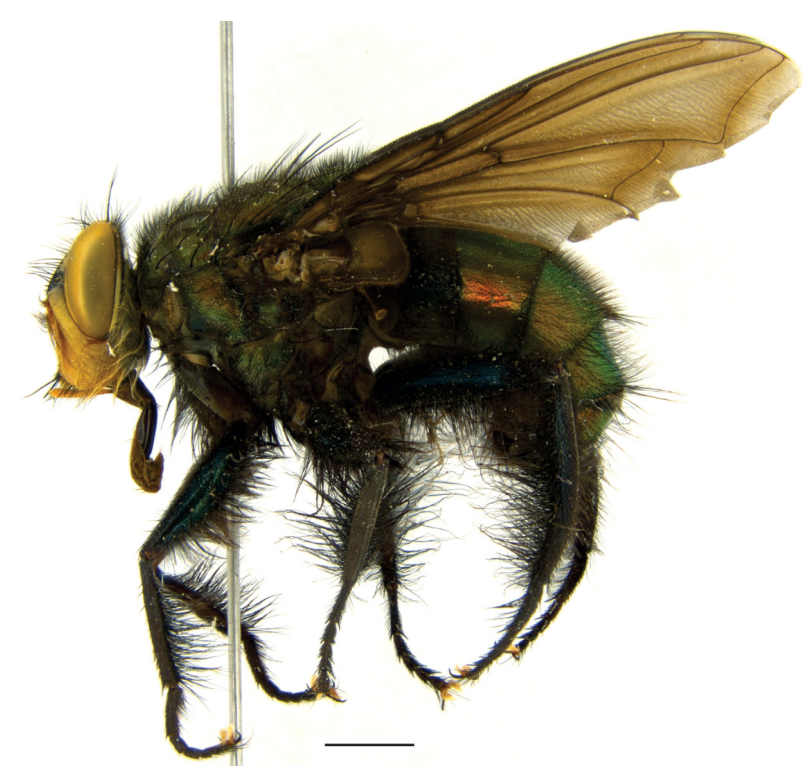

Figure 1. Adult of Blepharicnema splendens (LEUA-600). Scale bar $=2 \mathrm{~mm}$. (Credit: Yennifer Andrea Carreño Guevara). This figure is in color in the electronic version. 


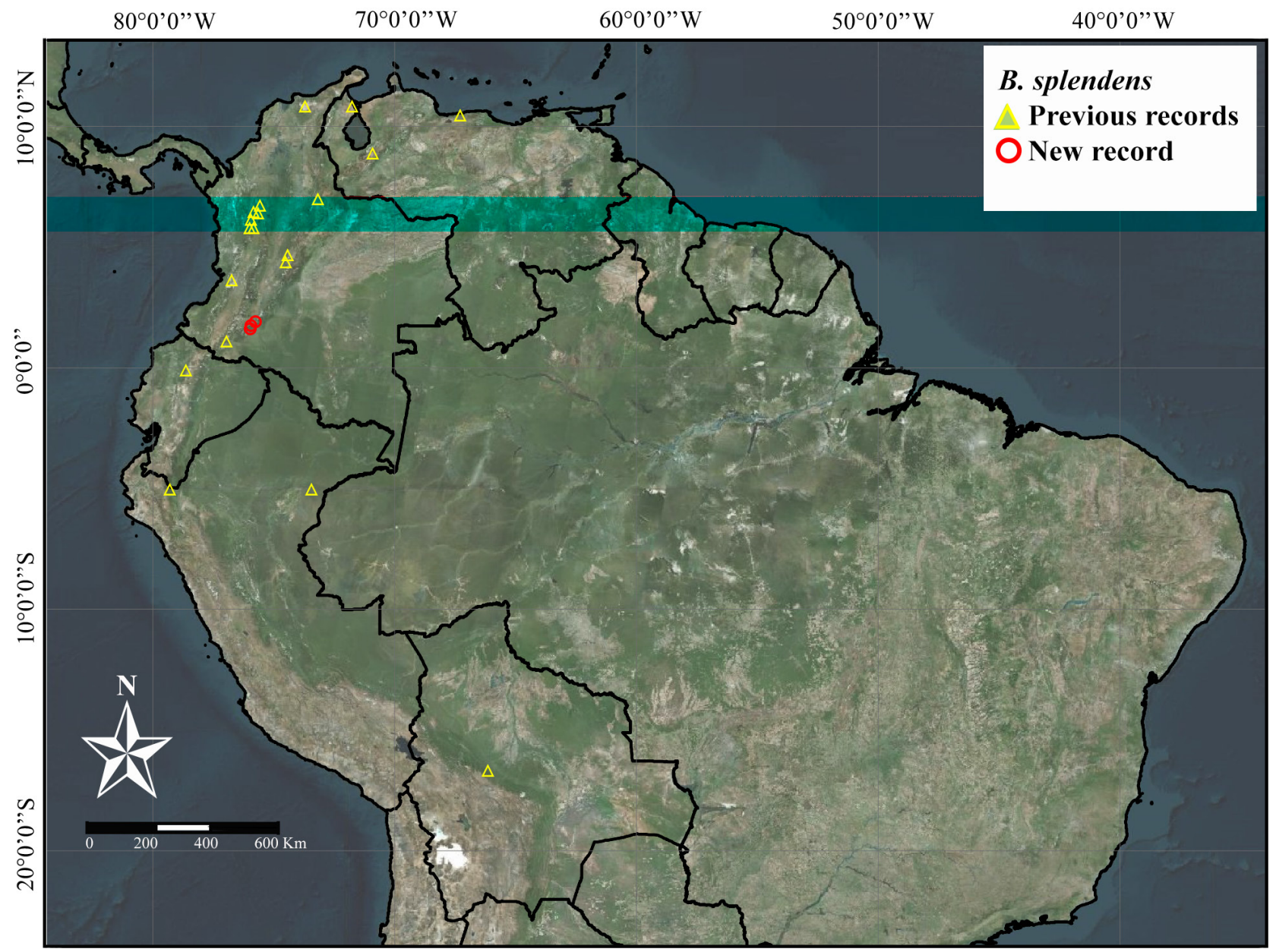

Figure 2. Distribution records of Blepharicnema splendens (Macquart, 1843). This figure is in color in the electronic version.

(male: LEUA-745; females: LEUA-746 to 757). 19.ii.2018, $10^{7}, 2$ ㅇ, Y. Ramos-Pastrana, Vsr. Trap baited with fish (male: LEUA-758; females: LEUA-759, LEUA-760). 20.ii.2018, $10^{\prime}, 69$, Y. Ramos-Pastrana, Vsr. Trap baited with fish (male: LEUA-761; females: LEUA-762 to 767). 21.ii.2018, 39, Y. Ramos-Pastrana, Vsr. Trap baited with fish (LEUA-768 to 770). 21.ii.2018, 19, Y. Ramos-Pastrana, jama (LEUA-771). Vereda Los Lirios, 1.400 m, 14.xi.2011, 29, Y. Ramos-Pastrana, Vsr. Trap baited with fish (LEUA-772, LEUA-773). Vereda Tarqui, 2020 m, 9.x.2014, 20', 40\%, Y. Ramos-Pastrana, Vsr. Trap baited with fish (males: LEUA-774, LEUA-775; females: LEUA-776 to 815). 4.x.2014, 49, Y. Ramos-Pastrana, Vsr. Trap baited with fish (LEUA-816 to 819). 6.x.2016, 19, Y. RamosPastrana, Vsr. Trap baited with fish (LEUA-820).

Diagnosis. Large-sized specimens (>12 $\mathrm{mm}$ in length), thorax with presutural acrostic setae, thorax and abdomen metallic green, legs with abundant long hairs.

Distribution. South America: Bolivia (Cochabamba, Chapare) (Mariluis and Peris 1984); Ecuador (Pichincha, Quito) (Walker 1858, in James 1970); Peru (Cajamarca, San
Ignacio, Distrito de Nambelle, Cuenca del Río Chinchipe) (Amanzo et al. 2003); Venezuela (Maracaibo, Distrito Federal, Caracas, Merida); Colombia (Antioquia, Medellín, San Antonio de Prado, El Retiro, Andes, Barbosa; Caldas, Manizales; Cundinamarca, Fusagasugá, Magdalena, Sierra Nevada de Santa Marta; Putumayo, Mocoa, Risaralda, Santuario de Fauna y Flora Otún-Quimbaya; Santander, Piedecuesta; Valle del Cauca, Farallones de Cali) (Amat and 2007), Caquetá, Florencia, new record (this study).

In Colombia, B. splendens had been reported mostly in montane forests with little human intervention, at 2,500 masl (Amat and Wolff 2007). We report its occurrence in montane and cloud forests at altitudes from 1,400 and 2,400 masl, in highly preserved areas, which indicates that $B$. splendens can be found at lower altitudes than previously reported. At Vereda Las Brisas, where the highest abundance of B. splendens was recorded, the climate and ecological characteristics are optimal for the occurrence of the species, with a predominance of wooded areas with diverse tree, herbaceous and shrub species (Amat and Wolff 2007). 
The diversity of calliphorids in the Department of Caquetá is still largely unknown. The last report on the species in Colombia date 11 years ago (Amat and Wolff 2007). With this record, the distribution of the species is expanded and further surveys are likely to reveal a wider distribution and abundance of this species in the Colombian mountainous ecosystems.

\section{ACKNOWLEDGMENTS}

To Universidad de la Amazonia and Colciencias, Project 113171249749-49749-2015, to Semillero de Investigación en Entomología (SIEN) of Universidad de la Amazonia and Universidad de Antioquia, to engineer Yennifer Andrea Carreño Guevara, for the photograph of B. splendens, and to biologist Cornelio Bota for the elaboration of the map of the geographical locations of $B$. splendens records.

\section{REFERENCES}

Amanzo, J.; Aacosta, R.; Aguilar, C.; Eckhard, K.; Severo, B.; Pequeño, T. 2003. Evaluación biológica rápida del Santuario Nacional Tabaconas-Nambelle y zonas aledañas. WWF, INRENA, Perú, 212p.

Amat, E.; Wolff, M. 2007. New Records of Blepharicnema splendens Macquart, 1843 (Calliphoridae, Calliphorinae, Luciliini) from Colombia. Revista de la Sociedad Entomológica Argentina, 66: 187-190.

Amat, E.; Vélez, M.C.; Wolff, M. 2008. Clave ilustrada para la identificación de los géneros y las especies de califóridos (Diptera: Calliphoridae) de Colombia. Caldasia, 30: 231-244.

ArcGIS (2018). (https://www.arcgis.com/index.html). Accessed on 02/04/2019.

Holdridge, L. 1996. Ecología Basada en Zonas de Vida. Instituto Interamericano de Cooperación para la Agricultura, IICA, San José de Costa Rica. 225p.

IGAC. 2010. Caquetá, características geográficas. Instituto Geográfico Agustín Codazzi, Bogotá, Colombia. 376p.
James, M.T. 1970. Family Calliphoridae. In: Papavero, N. (Ed.). A Catalogue of the America South of the United States. Museu de Zoologia, Universidad de São Paulo, São Paulo. Brazil, p.1-28.

Kosmann, A.C.; Pinto, D.E; Mello, R.; Harterreiten-Souza, S.E.; Pujol-Luz, J.R. 2013. A list of current valid blow fly names (Diptera: Calliphoridae) in the Americas South of Mexico with key to the Brazilian species. EntomoBrasilis, 6: 74-85.

Macquart, J.P.M. 1843. Dipteres exotiquez nouveaux peu connus. Memories de la Société (Royale) des Sciences, de l'Agricultura et des Arts à Lille, 283.

Mariluis, J.C. 1979. El género Blepharicnema Macquart, 1843 (Calliphoridae, Calliphorinae, Luciliini). Revista de la Sociedad Entomológica Aragonesa, 38: 137-142.

Mariluis, J.C.; Peris, S.V. 1984. Datos para una sinopsis de los Calliphoridae Neotropicales. Eos, LX: 67-86.

Pape, T.; Wolff, M.; Amat, E. 2004. The blow flies, bot flies, woodlouse flies and flesh flies (Diptera: Calliphoridae, Oestridae, Rhinophoridae, Sarcophagidae) of Colombia. Biota Colombiana, 5: 201-208.

Thompson, F.C. 2008. The díptera site. The biosystematic database of world díptera. Nomenclátor status statistics. Versión 10.5. (http://www.sel.barc.usda.gov/diptera/names/Status/bdwdstat. htm) Accessed on 26/01/2018.

Vargas, J.; Wood, D.M. 2010. Calliphoridae (blow flies). In: Brown, B.V.; Borkent, A.; Cumming, J.M.; Wood, M.D.; Woodley, N.E.; Zumbado, M.A. (Ed.). Manual of Central American Diptera. v.2. National Research Council of Canada, Monograph Publishing Program, Ottawa, p.1297-1304.

Wolff, M.; Kosmann, C. 2016. Families Calliphoridae and Mesembrinellidae. Zootaxa, 4122: 856-875.

RECEIVED: 04/09/2018

ACCEPTED: $23 / 03 / 2019$

ASSOCIATE EDITOR: Pitágoras C. Bispo 